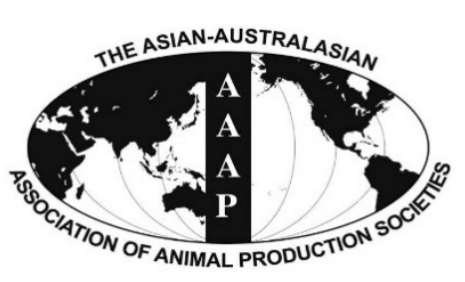

Open Access

Asian Australas. J. Anim. Sci.

Vol. 29, No. 11 : 1523-1529 November 2016

http://dx.doi.org/10.5713/ajas.15.0627

www.ajas.info

pISSN 1011-2367 elSSN 1976-5517

\title{
Role of Fermentation in Improving Nutritional Quality of Soybean Meal - A Review
}

\author{
Runni Mukherjee, Runu Chakraborty*, and Abhishek Dutta ${ }^{1}$ \\ Department of Food Technology and Biochemical Engineering, Jadavpur University, Kolkata 700 032, India
}

\begin{abstract}
Soybean meal (SBM), a commonly used protein source for animal feed, contains anti-nutritional factors such as trypsin inhibitor, phytate, oligosaccharides among others, which limit its utilization. Microbial fermentation using bacteria or fungi has the capability to improve nutritional value of SBM by altering the native composition. Both submerged and solid state fermentation processes can be used for this purpose. Bacterial and fungal fermentations result in degradation of various anti-nutritional factors, an increase in amount of small-sized peptides and improved content of both essential and non-essential amino acids. However, the resulting fermented products vary in levels of nutritional components as the two species used for fermentation differ in their metabolic activities. Compared to SBM, feeding non-ruminants with fermented SBM has several beneficial effects including increased average daily gain, improved growth performance, better protein digestibility, decreased immunological reactivity and undesirable morphological changes like absence of granulated pinocytotic vacuoles. (Key Words: Amino Acids, Anti-nutritional Factors, Soybean Meal, Fermentation, Non-ruminants)
\end{abstract}

\section{INTRODUCTION}

Soybean (SB) (Glycine max [L.] Merrill) is a legume native to Asia, widely grown for its consumption as nonfermented (soymilk, tofu, soy nuts, etc.) and fermented (miso, sufu, natto, etc.) products. Soy-based foods are known to have good nutritional and functional qualities, not only due to their high protein and oil content but also because of phytochemicals, notably the isoflavones (Kishida et al., 2000). Acceptance of SB protein products as animal feed has increased because of low cost and high nutritional value with a good amino acid (AA) balance (Frias et al., 2008). However, raw SB is toxic to nonruminants due to the presence of high concentration of serine protease inhibitors or trypsin inhibitors (TI) (Dunsford et al., 1989; Li et al., 1990).

Processing of SB produces a wide variety of useful

\footnotetext{
* Corresponding Author: Runu Chakraborty. Tel: +91-3324146822, E-mail: crunu@hotmail.com

${ }^{1}$ Faculteit Industriële Ingenieurswetenschappen, KU Leuven, Campus Groep T Leuven, Leuven B-3000, Belgium.

Submitted Jul. 27, 2015; Revised Oct. 12, 2015; Accepted Dec. 1, 2015
}

products such as meal, oil, lecithin, and others. Soybean meal (SBM) is the material remaining after extraction of oil from SB flakes, with about $48 \%$ crude protein (CP) content. Apart from being a protein rich product, SBM contains significant amount of anti-nutritional factors and those need to be eliminated to increase its acceptability (Dunsford et al., 1989; Li et al., 1990). Fermented SBM (FSBM) is produced from SBM using fungal and bacterial strains (predominantly Aspergillus oryzae and Lactobacillus subtilis, respectively). Several studies (Hirabayashi et al., 1998; Hong et al., 2004; Song et al., 2008) have reported numerous benefits of FSBM including degradation of SB allergens during fermentation by microbial proteolytic enzymes. Fermentation process efficiently eliminates antinutritive compounds and improves nutritional value of SBM (Hong et al., 2004). The beneficial effects of feeding FSBM based diets to a variety of ruminants as well as nonruminants, both young and adult, have also been investigated and established (Mathivanan et al., 2006; Song et al., 2008; Yuan et al., 2012). Increase in the majority of growth promoting factors as well as health parameters are seen in farm and poultry animals (Feng et al., 2007a, b; Liu 
et al., 2007; Kwon et al., 2011). FSBM based diet is also recommended for certain fish species as a replacement of fish meal in several studies (Yamamoto et al., 2010; Kader et al., 2012; Yuan et al., 2012).

Although a lot of research has been performed involving FSBM, to the best of our knowledge no such review on fermentation of SBM has been written so far. The objective of this review is to discuss the fermentation processes of SBM, and the benefits associated with it. Further, the positive effects of feeding FSBM to ruminants and nonruminants are also discussed.

\section{SOYBEAN MEAL}

After the oil has been extracted from SB, the residual meal is used as a supplemental protein source for livestock. The CP content of the SBM ranges from 410 to $500 \mathrm{~g} / \mathrm{kg}$ (dry basis) depending upon the amount of hull and processing method. Depending on the requirement of $\mathrm{CP}$ content, a $410 \mathrm{~g} / \mathrm{kg} \mathrm{CP}$ content of SBM is produced by expeller or hydraulically pressing SB that have not had the hulls removed or undecorticated, while the $440 \mathrm{~g} / \mathrm{kg} \mathrm{CP}$ content of SBM is produced by solvent extracting SB without removing the hulls. However, a $500 \mathrm{~g} / \mathrm{kg} \mathrm{CP}$ content of SBM would have the hulls removed prior to having the oil extracted using solvent like hexane. SBM is not only rich in protein, but also contains almost all the essential and non-essential AAs in good ratio except the two sulfur containing AAs. Glutamic acid is present in largest amount followed by aspartic acid, arginine, alanine, glycine and serine, and proline in SBM. Among the essential AAs, leucine has the highest concentration, followed by lysine, isoleucine, valine, threonine, tyrosine, phenylalanine and histidine. In lower amounts are cysteine and methionine (Hong et al., 2004; Song et al., 2008).

Plant proteins, such as SBM, are less expensive than animal protein sources but contain anti-nutritional factors that limit the application of SBM in animal feed, especially for young pigs (Dunsford et al., 1989; Li et al., 1990; Songet al., 2010) and as the sole protein source for some animals including pig (Li et al., 1990; Qin et al., 1996). Predominant anti-nutritional factors associated with SBM include TI, saponins, phytoestrogens, glucinins, goitrogens, lectins, mineral binding substances and several additional factors (Liener, 1994). TIs interfere with the functions of trypsin and chymotrypsin. These enzymes aid in the digestion of dietary proteins that have been consumed by an animal. The TIs bind to enzymes, making them nonfunctional impairing protein digestion (Liener, 1994). These have the greatest effect on non-ruminants, such as, poultry and swine. Phytoestrogens have been shown to cause infertility problems in sheep and cattle (Adams et al., 1995). Lectins interfere with absorption of nutrients in the small intestine (Liener, 1994). Phytic acid makes phosphorus and zinc less available to the animal. In order to maximize the nutritional quality of SBM and for a wider acceptability, these anti-nutritional factors need to be inactivated or minimized.

\section{FERMENTED SOYBEAN MEAL}

Fermentation is one of the oldest forms of food processing and preservation (Ross et al., 2002), and also has the capacity to improve nutritional and functional properties of the original product (Frias et al., 2008). Fermentation has been widely used to increase the bioavailability of nutrients (Hotz and Gibson, 2007) and reduce the levels of antinutritional factors (Egounlety and Aworh, 2003) of SB. Several studies (Kishida et al., 2000; Frias et al., 2008; Song et al., 2008) have also confirmed the ability of fermentation process in degrading anti-nutritive and allergenic compounds of SBM, thereby increasing the possibilities of utilization of various processed products of SB. A wide variety of microorganisms have been used to ferment SBM for nutritional enhancement. The fermentation process is facilitated by the use of a mold or a bacterium. The fermentation conditions and nutritional quality of the FSBM thus produced can vary depending on the type of microorganism used. Aspergillus is the most popular species due to its capacity to produce enzymes such as hemicellulases, hydrolases, pectinases, protease, amylase, lipases, and tannases (Pinto et al., 2001; Mathivanan et al., 2006). In case of bacterial fermentation, various Lactobacillus species and Bacillus subtilis are preferred (Yang et al., 2007).

\section{Microbial fermentation of soybean meal}

Microbial fermentation of SBM is achieved using a fungi or a bacterial strain. The fermentation process can be a solid state fermentation or a submerged fermentation and SBM can be subjected to both processes depending on its state i.e. crude without any alteration of moisture content or texture of SBM or dried and grounded flour to make fine particles which are readily dissolvable in water. The former approach, being an alternative to the latter approach, has numerous advantages including productivity and cost due to the possibility of using agro-industrial residues and/or byproducts as nutrient source, as well as support for microorganism development (Rigo et al., 2010). Much like submerged fermentation, the process related to solid state fermentation has been reported to upgrade the nutritional quality of SBM that can be used in aqua-feed and animal feed industries (Singh et al., 1990; Lena et al., 1997) and is increasingly being employed for SBM fermentation. The peptides content and fibrinolytic enzyme activity increased and the anti-nutrition factors reduced after fermentation 
effectively. Solid state fermentation also resulted in an increase of in vitro trypsin digestibility and nitrogen solubility under alkaline conditions (Amadou et al., 2010a) and improvement of the nutritional quality of SBM. The efficiency of solid state fermentation in improving nutritional quality and reducing the anti-nutritional factors were ascertained by the works of Amadou et al. (2010a, b).

Fungi-based fermentation: Several species of Aspergillus genus have been used to ferment SBM like $A$. oryzae (Feng et al., 2007a, b; Liu et al., 2007), A. usamii (Hirabayashi et al., 1998), A. awamori (Kishida et al., 2000), A. niger (Mathivanan et al., 2006) to name a few. Zamora and Veum (1979) work on fermentation of dehulled SB with A. oryzae and Rhizopus oligoporous established the importance of fermentation in nutritional quality improvement and also created the path for future research works on FSBM. Beneficial effects of fungi-based fermentation on SB and SBM are well documented (Ilyas et al., 1995; Hong et al., 2004; Liu et al., 2007). Fungal fermentation using $A$. oryzae eliminated TI from $2.6 \mathrm{mg} / \mathrm{g}$ to zero, as reported by Liu et al. (2007) and Feng et al. (2007b). Reduction of TI and large size protein content in FSBM has several beneficial effects when fed to nonruminants such as poultry and swine. Fermentation with Aspergilli almost completely eliminates phytate, resulting in a protein source for feed with highly available phosphorus (Ilyas et al., 1995) as well as zinc (Hirabayashi et al., 1998). Fermentation with fungi also successfully reduces the amount of stachyose and raffinose in SBM which contains approximately $52 \mathrm{~g} / \mathrm{kg}$ stchyose and $11 \mathrm{~g} / \mathrm{kg}$ raffinose (Cervantes-Pahm and Stein, 2010). SBM also has approximately $78 \mathrm{~g} / \mathrm{kg}$ sucrose whereas FSBM contains none (Cervantes-Pahm and Stein, 2010). Breakdown of carbohydrates can be attributed to the $\alpha$-galactosidase produced by Aspergilli used in fermentation. Apart from degrading the anti-nutritional factors, fungal fermentation increases the nutritional value of feed by increasing the crude fat, crude ash, dry matter and CP contents (Hong et al., 2004; Feng, et al., 2007a, b). The increases in protein and fat contents may partially be attributed to the decrease in carbohydrate content during fermentation. Fermentation also significantly increases small size peptides $(<15 \mathrm{kD})$ in FSBM (Hirabayashi et al., 1998) as long-chained proteins are broken down. An experiment with mice showed that fermentation converts glycones into the corresponding aglycones, which are absorbed more readily and efficiently (Kishida et al., 2000).

Though FSBM has approximately $10 \%$ more CP than SBM, essential AA profile remains unchanged after fungal fermentation (Zamora and Veum, 1979; Hong et al., 2004). According to Hong et al. (2004), fermentation of SBM with A. oryzae did not affect the essential AA concentration but increased the concentrations of glycine, glutamine, and aspartic acid. This finding is in partial agreement with the results of Frias et al. (2008), in which the contents of most of essential AAs improved. In addition, Hong et al. (2004) showed that A. oryzae also presented a preference for specific AAs rather than all. These findings are in harmony with the suggestion that increases in the concentration of certain AAs as well as the changes in AA profile of FSBM could be attributed to microbial metabolism that takes place during SBM fermentation (Frias et al., 2008).

Bacteria-based fermentation: Traditionally, Bacillus spp. has been used to produce fermented soy based foods (Hanet al., 2001). For example, the Japanese fermented SB natto is made by adding the bacteria $B$. subtilis to SB. Similar to fungal fermentation, bacterial strains also degrade various anti-nutritional factors of SBM including TI. Lactobacillus plantarum is another bacterial strain which has frequently been used to ferment SBM (Amadou et al., 2010a, b; Amadou et al., 2011). Fermentation with lactic acid bacteria like $L$. plantarum results in protein hydrolysis and increased liberation of free AAs, thus the resulting FSBM has significantly higher total free AA content as compared to SBM. However, histidine, threonine, methionine and phenylalanine contents do not change whereas leucine, isoleucine, aspartic acid and proline increase after fermentation (Amadou et al., 2010b). These findings are equivalent to the findings of Hong et al. (2004). When SBM is subjected to fermentation by $B$. subtilis, the concentration of small-size proteins increases along with the contents of arginine, serine, threonine, aspartic acid, alanine andglycine but proline content decreases (Teng et al., 2012). Different proteinase profiles, secretion abilities and fermentation temperatures of the two organisms are possibly are the reasons behind the differences in the AA profiles of the resulting FSBM.

Much like fungal fermentation, bacterial fermentation also decreases the protein size, which can be attributed to the enzymes of L. plantarum and to the fermentation process itself (Hong et al., 2004). In vitro trypsin digestibility also increases after fermentation, thereby improving nutritional and functional properties compared to the SBM (Frias et al., 2008; Amadou et al., 2010a). Fermentation with bacterial strains results in a higher antioxidant activity, too. The increased concentrations of certain AAs such as Histidine, Serine, Valine and Lysine after fermentation are thought to have a relation with the increased antioxidant property (Amadou et al., 2011). Concentrations of phenolic compounds also increase in SBM after fermentation, thereby increasing both antioxidant and metal chelating activity (Moktan et al., 2008). Fermentation of SBM using B. subtilis results in FSBM having higher CP and lower TI content compared to SBM (Teng et al., 2012). These findings supported the fact that fermentation of SBM is indeed a complex process 
which is strongly controlled by the enzymes involved and thus the type of the organism selected for fermentation is one of the major factors in determining the levels of various nutritional components in the FSBM.

\section{Comparison of fungal and bacterial fermentation}

Several research groups (Frias et al., 2008; Song et al., 2008; Teng et al., 2012) had tried to compare the nutritional quality of the FSBM produced by both fungal and bacterial fermentation. The dissimilarity in the resulting FSBM can be attributed to the different metabolic activities and enzymes involved of the two species utilized for fermentation although in both the fermentations, the antinutrients decrease and nutritional quality improves. However, there are significant differences in the level of variations for certain components. Table 1 compares the differences in nutritional values of unfermented and FSBM. A fermentation study (Teng et al., 2012) involving $A$. oryzae and $B$. subtilis showed consistent increase in CP during fermentation which occurs due to microbial growth. However, the proportion of soluble protein increased by $19.4 \%$ and $63.11 \%$, respectively, which may occur due to stronger hydrolysis by $B$. subtilis under fermentation conditions. The percentages of degradation of TI for both fermentations were of comparable values; while fermentation with fungi reduced TI by $81.33 \%$, bacterial fermentation resulted in $95.33 \%$ reduction. Increase in antioxidant activity was also of equivalent levels. But in the case of in vitro digestibility of SBM and degradation of antigenic proteins, B. subtilis was found to be more efficient. Studies done with yeast (Saccharomyces cereviseae) and bacterial strains (L. plantarum and Bifidobacterium lactis) by Song et al. (2008) indicated that both fermentations significantly reduce the immunoreactivity of SBM which is a major benefit in terms of acceptability and health issues. Both fermentations resulted in breakdown of larger antigenic proteins, thereby considerably increasing the amount of smaller size peptides $(15 \mathrm{kD})$ in FSBM and reducing the immunoreactivity. These findings are in partial agreement with other study (Frias et al., 2008) which found that fermentation with $A$. oryzae or $R$. oryzae resulted in much lower reduction in immunoreactivity compared to fermentation with B. subtilis or L. plantarum, thus making the bacterial strains a better choice for reducing the immunoreactivity of SBM. This may be attributed to the fact that slower growing fungi results in less viable microorganisms, generating lower epitomes alteration and thus higher immunoreactivity compared to the bacterial fermented product.

While comparing the AA contents of products from yeast and bacterial fermentations (Song et al., 2008) it is found that among the essential AAs isoleucine and methionine amounts did not change significantly after fermentation (both bacterial and yeast fermentations), whereas during bacterial fermentation cysteine decreases. Taking into consideration the original concentrations of essential AAs in SBM, fermentation with S. cerevisae can be recommended due to a sharp increase in cysteine, an essential AA that is present in lower concentration in SBM (Song et al., 2008). In case of fermentations with fungal and bacterial stains, the changes in the AA profile are comparable with increase in majority of the essential and non-essential AA contents (Frias et al., 2008; Teng et al., 2012). The variations in the AA profiles may arise due to the differences in proteinase profiles and secretion abilities of the organisms. These findings indicate that the choice of microorganism for fermentation should be done according to the nutritional requirement of the final fermented product.

\section{Beneficial effects of feeding fermented soybean meal}

As mentioned earlier, beneficial effects of feeding FSBM to farm animals like swine (Feng et al., 2007b; Liu et al., 2007) and poultry (Mukherjee et al., 2015) have been widely evaluated and documented. Table 2 summarizes the works of various research groups who have evaluated effects of feeding FSBM to various non-ruminants as well as some ruminants.

Rats when fed with FSBM show increase in average daily gain and gain-to-feed ratio (Zamora and Veum, 1979). Similar observations are seen in pigs where the average daily gain and gain-to-feed ratio increase by $8.33 \%$ and $5.56 \%$, respectively (Feng et al., 2007b), and also in broilers where the average daily gain improves by around $18 \%$ (Feng et al., 2007a). An experiment with 3 weeks-old

Table 1. Comparison of nutritional quality of unfermented, fungi-fermented and bacteria-fermented soybean meal ${ }^{1}$

\begin{tabular}{lccc}
\hline \multirow{2}{*}{$\begin{array}{c}\text { Nutritional components } \\
\text { affected by fermentation }\end{array}$} & Unfermented soybean meal & \multicolumn{2}{c}{ Types of organism used for fermentation } \\
\cline { 3 - 4 } & & \multicolumn{2}{c}{ Fermented soybean meal } \\
\hline Crude protein content (\%) & 34.5 & 37.4 & 37.5 \\
Soluble protein content (\%) & 20 & 24 & 33 \\
In-vitro digestibility (pepsin) & 60.5 & 67.4 & 76 \\
Anti-oxidant activity (\%) & 8 & 27 & 38 \\
Small-sized peptides (<15 kD) $(\%)$ & 5 & 35 & 63 \\
\hline
\end{tabular}

${ }^{1}$ Hong et al., 2004; Teng et al., 2012. 
Table 2. Summary of works done on FSBM: Microorganisms used for fermenting soybean meal, the corresponding animals that are fed with the FSBM and the beneficial effects of fermentation along with the corresponding references

\begin{tabular}{|c|c|c|c|c|}
\hline Substrate & Microorganisms used & $\begin{array}{l}\text { Animal trial } \\
\text { carried out on }\end{array}$ & Beneficial effects/nutritional improvement & Reference \\
\hline $\begin{array}{l}\text { FSBM and squid } \\
\text { by-product blend }\end{array}$ & Bacillus spp. & Fish & $\begin{array}{l}\text { An alternative protein ingredient in aqua feed and can } \\
\text { replace } 36 \% \text { FM protein in the diet of Japanese flounder }\end{array}$ & $\begin{array}{l}\text { Kader et al. } \\
\quad(2012)\end{array}$ \\
\hline Soybean meal & $\begin{array}{l}\text { Aspergillus oryzae and } \\
\text { Bacillus subtilis }\end{array}$ & - & $\begin{array}{l}\text { Increase in } \mathrm{CP} \text {, small-sized proteins, arginine, serine, } \\
\text { threonine, aspartic acid, alanine and glycine contents; } \\
\text { decrease in TI, proline contents }\end{array}$ & $\begin{array}{l}\text { Teng et al. } \\
\text { (2012) }\end{array}$ \\
\hline $\begin{array}{l}\text { PepSoyGen } \\
\quad \text { (commercial FSBM) }\end{array}$ & Aspergillus Oryzae GB-107 & Fish & $\begin{array}{l}\text { FSBM is an acceptable alternative plant protein source that } \\
\text { can replace up to } 35 \% \text { of fish meal protein in diets without } \\
\text { significant adverse effects on growth, survival, FCR, PER, } \\
\text { and body composition }\end{array}$ & $\begin{array}{l}\text { Yuan et al. } \\
\text { (2012) }\end{array}$ \\
\hline $\begin{array}{l}\text { PepSoyGen } \\
\quad \text { (commercial FSBM) }\end{array}$ & Aspergillus Oryzae GB-107 & $\begin{array}{l}\text { Lipopolysaccharide } \\
\text { challenged calves }\end{array}$ & $\begin{array}{l}\text { Increased higher LPS-specific IgG, concentration of serum } \\
\text { haptoglobin; decreased weaning stress }\end{array}$ & $\begin{array}{l}\text { Kwon et al. } \\
\text { (2011) }\end{array}$ \\
\hline Soybean meal & $\begin{array}{l}\text { Lactobacillus plantarum } \\
\text { Lp6 }\end{array}$ & - & $\begin{array}{l}\text { Increase in leucine, isoleucine, valine, aspartic acid and } \\
\text { proline contents; decrease in TI content }\end{array}$ & $\begin{array}{l}\text { Amadou et al. } \\
\quad(2010)\end{array}$ \\
\hline $\begin{array}{l}\text { PepSoyGen } \\
\text { (commercial FSBM) }\end{array}$ & Aspergillus Oryzae GB-107 & Piglets & Increased growth performance & $\begin{array}{l}\text { Jones et al. } \\
\text { (2010) }\end{array}$ \\
\hline $\begin{array}{l}\text { PepSoyGen } \\
\text { (commercial FSBM) }\end{array}$ & Aspergillus Oryzae GB-107 & Piglets & hypoallergenic fermented soybean product & $\begin{array}{l}\text { Song et al. } \\
\text { (2010) }\end{array}$ \\
\hline Soybean meal & Bacillus spp. & Fish & $\begin{array}{l}\text { A promising ingredient as the main protein source in a non- } \\
\text { fish meal diet for rainbow trout }\end{array}$ & $\begin{array}{l}\text { Yamamoto et al. } \\
\text { (2010) }\end{array}$ \\
\hline Soybean meal & $\begin{array}{l}\text { Lactobacillus plantarum, } \\
\text { Bifidobacterium lactis and } \\
\text { Saccharomyces cereviseae }\end{array}$ & Piglets & $\begin{array}{l}\text { Increase in essential and non-essential amino acid contents; } \\
\text { decrease in IgE immunoreactivity }\end{array}$ & $\begin{array}{l}\text { Song et al. } \\
\text { (2008) }\end{array}$ \\
\hline Soy flour & $\begin{array}{l}\text { Lactobacillus plantarum, } \\
\text { Bacillus subtilis, Aspergillus } \\
\text { oryzae and Rhizopusoryzae }\end{array}$ & - & $\begin{array}{l}\text { Increased amino acid content; decreased in immunire } \\
\text { acivity }\end{array}$ & $\begin{array}{l}\text { Frias et al. } \\
\quad(2008)\end{array}$ \\
\hline Soybean meal & Aspergillus oryzae 3.042 & Poultry & $\begin{array}{l}\text { Increasedaverage daily gain, average daily feed intake, } \\
\text { feed conversion (in growing period), phosphorus, IgM } \\
\text { and IgA (in growing period) content in serum; decreased } \\
\text { urea nitrogen content of serum }\end{array}$ & $\begin{array}{l}\text { Feng et al. } \\
\text { (2007a) }\end{array}$ \\
\hline Soybean meal & Aspergillus oryzae & Piglets & $\begin{array}{l}\text { Increasedaverage daily gain,activities of total protease and } \\
\text { trypsin; decreased feed gain ratio }\end{array}$ & $\begin{array}{l}\text { Feng et al. } \\
\text { (2007b) }\end{array}$ \\
\hline Soybean meal & Aspergillus oryzae 3.042 & Piglets & $\begin{array}{l}\text { Increased average daily gain; decreased feed gain ratio, } \\
\text { serum IgG }\end{array}$ & $\begin{array}{l}\text { Liu et al. } \\
\text { (2007) }\end{array}$ \\
\hline Soybean meal & Aspergillus niger & Poultry & Increase in body weight, ileum villi length and width & $\begin{array}{l}\text { Mathivanan } \\
\text { et al. (2006) }\end{array}$ \\
\hline $\begin{array}{l}\text { Soybean and } \\
\text { soybean meal }\end{array}$ & Aspergillus oryzae & Young animals & $\begin{array}{l}\text { Increased small-size peptide }(<20 \mathrm{kDa}) \text { content, CP } \\
\text { content; decreased TI content }\end{array}$ & $\begin{array}{l}\text { Hong et al. } \\
\text { (2004) }\end{array}$ \\
\hline Soybean & Aspergillus awamori & - & $\begin{array}{l}\text { Increased cytochrome P- } 450 \text { content, isoflavonoid } \\
\text { aglycone content; decreased pentobarbital sleeping time }\end{array}$ & $\begin{array}{l}\text { Kishida et al. } \\
\quad(2000)\end{array}$ \\
\hline Soybean meal & Aspergillus usamii & Rats & Complete degradation of phytic acid & $\begin{array}{l}\text { Ilyas et al. } \\
\text { (1995) }\end{array}$ \\
\hline Soybean meal & Aspergillus usamii & Poultry & $\begin{array}{l}\text { Increased body weight gain, the amount of retained } \\
\text { phosphorus, andfemoral phosphorus content; decrease in } \\
\text { phytate phosphorus (complete degradation) }\end{array}$ & $\begin{array}{l}\text { Hirabayashi } \\
\text { et al. (1998) }\end{array}$ \\
\hline
\end{tabular}

FSBM, fermented soybean meal; CP, crude protein; TI, trypsin inhibitor; Ig, immunoglobulin; LPS, lipopolysaccharide; FCR, feed conversion ratio; PER, protein efficiency ratio; FM, fish meal.

nursery pigs (Jones et al., 2010) showed that feeding dietscontaining FSBM can improve growth performance, compared to those fed with SBM. Chicks (1 week old) also showhighersolubility of zinc in eachsegment of small intestine (Hirabayashi et al., 1998). This can be attributed to the reduction inphytate content in FSBM. Feeding pigs (5 weeks old) FSBM increases trypsin activity as well as total protease in the duodenum and jejunum but no effect is seen in the ileum (Feng et al., 2007b). The improvement of protein digestibility in pigs may be due to the degradation of $\mathrm{TI}$ and reduction in large-size proteins in FSBM.

Broilers (one day old) fed with FSBM show higher serum $\operatorname{IgA}$ and $\operatorname{IgM}$ but serum IgG level is unchanged (Feng et al., 2007a). The growth promoting activities may also be associated with the greater supply of essential AAs and possible vitamin synthesis by fungi (Chah, et al., 1975). FSBM feeding also results in better digestibility in broilers due to a lower intestinal $\mathrm{pH}$ because of a higher level of 
volatile fatty acids production during fermentation and decreased viable count of pathogenic bacteria (Mathivananet al., 2006). In broilers (one day old), feeding FSBM improve mucosal structure of ileum villi (Mathivanan et al., 2006). FSBM induces significantly lower morphological changes such as disintegration of microvilli, absence of granulated pinocytotic vacuoles, etc in fingerling rainbow trouts (Yamamoto et al., 2010). Although there is significant increase in body weight and specific growth rate, there are no significant differences in whole body moisture content, CP and ash in the fish fed FSBM (Yamamoto et al., 2010; Kader et al., 2012). Feeding rainbow trouts with $\mathrm{FM}$ and FSBM results in higher hemoglobin and lower total plasma cholesterol concentration compared to fish fed only with FM (Yamamoto et al., 2010), implying that FM can be replaced partially with FSBM for fish feed making it more cost effective. When juvenile Japanese flounder fish are fed a diet containing FSBM, they exhibit increase in total serum protein concentration and a significantly lower bacterial activity (quantified as bacterial count in serum) (Kader et al., 2012). There is also no adverse effect on hematocrit and blood chemical parameters like total albumin, total bilirubin, etc. which are indicators of the physiological conditions of fish. These findings suggest that feeding FSBM results in better growth performance and healthier animals which can be attributed to the improvements brought about by fermentation in SBM. The positive effects of using FSBM as an alternatives evident in a variety of animals as it eliminates several problems associated with feeding SBM like immunoreactivity, low growth parameters and other health related issues.

\section{CONCLUSIONS}

FSBM is an appropriate alternative to SBM for use as animal feed. Fermentation does not only increase free AA content, small-sized peptides, CP content and bioavailability of nutrients, it also increases the acceptability of SBM by degrading anti-nutrients like phytate, TI and oligosaccharides. These effects can be attributed to the fermentation process itself as well as the microorganism used for this purpose. The choice of the organism for fermentation also has profound effect on the nutritional quality of the final FSBM as different strains have different enzyme systems and thus the levels of degradation and/or synthesis of different components vary significantly. Several beneficial effects, including increased average daily gain, improved growth performance, better protein digestibility, decreased immunological reactivity and undesirable morphological changes, are observed when FSBM is fed to non-ruminants. Further studies on this subject are required to develop products based on these facts, thereby creating a wider acceptability of FSBM-based products.

\section{AUTHOR CONTRIBUTIONS}

$\mathrm{RM}$ collected, read and organized all the necessary information and drafted the manuscript. $\mathrm{AD}$ and $\mathrm{RC}$ revised the manuscript critically for necessary intellectual content, reviewed the content and gave final approval of the version to be published. All authors read and approved the final manuscript.

\section{CONFLICT OF INTEREST}

The authors certify that there is no conflict of interest with any financial organization regarding the material discussed in the manuscript.

\section{REFERENCES}

Adams, N. R. 1995. Detection of the effects of phytoestrogens on sheep and cattle. J. Anim. Sci. 73:1509-1515.

Amadou, I., A. Tidjani, M. B. K. Foh, M. T. Kamara, and G. W. Le. 2010a. Influence of Lactobacillus plantarum Lp6 fermentation on the functional properties of soybean protein meal. Emir. J. Food Agric. 22:456-465.

Amadou, I., M. T. Kamara, A. Tidjani, M. B. K. Foh, and G. W. Le. 2010b. Physicochemical and nutritional analysis of fermented soybean protein meal by Lactobacillus plantarum Lp6. World J. Dairy Food Sci. 5:114-118.

Amadou, I., G. W. Le, Y. H. Shi, and S. Jin. 2011. Reducing, radical scavenging, and chelation properties of fermented soy protein meal hydrolysate by Lactobacillus plantarum Lp6. Int. J. Food Prop. 14:654-665.

Chah, C. C., C. W. Carlson, G. Semeniuk, I. S. Palmer, and C. W. Hesseltine. 1975. Growth promoting effects of fermented soyabeans for broilers. Poult. Sci. 54:600-609.

Cervantes-Pahm, S. K. and H. H. Stein. 2010. Ileal digestibility of amino acids in conventional, fermented, and enzyme-treated soybean meal and in soy protein isolate, fish meal, and casein fed to weanling pigs. J. Anim. Sci. 88:2674-2683.

Dunsford, B. R., D. A. Knabe, and W. E. Hacnsly. 1989. Effect of dietary soybean meal on the microscopic anatomy of the small intestine in the early-weaned pig. J. Anim. Sci. 67:1855-1864.

Egounlety, M. and O. C. Aworh. 2003. Effect of soaking, dehulling, cooking and fermentation with Rhizopus oligosporus on the oligosaccharides, trypsin inhibitor, phytic acid and tannins of soybean (Glycine max Merr.), cowpea (Vigna unguiculata L. Walp) and ground bean (Macrotyloma geocarpa Harms). J. Food Eng. 56:249-254.

Feng, J., X. Liu, Z. R. Xu, Y. Y. Liu, and Y. P. Lu. 2007a. Effects of Aspergillus oryzae 3.042 fermented soybean meal on growth performance and plasma biochemical parameters in broilers. Anim. Feed Sci. Technol. 134:235-242.

Feng, J., X. Liu, Z. R. Xu, Y. P. Lu, and Y. Y. Liu. 2007b. The 
effect of Aspergillus oryzae fermented soybean meal on growth performance, digestibility of dietary components and activities of intestinal enzymes in weaned piglets. Anim. Feed Sci. Technol. 134:295-303.

Frias, J., Y. S. Song, C. Martínez-Villaluenga, E. G. De Mejia, and C. Vidal-Valverde. 2008. Immunoreactivity and amino acid content of fermented soybean products. J. Agric. Food Chem. 56:99-105.

Han, B. Z., F. M. Rombouts, and M. J. R. Nout. 2001. A Chinese fermented soybean food. Int. J. Food Microbiol. 65:1-10.

Hirabayashi, M., T. Matsui, H. Yano, and T. Nakajima. 1998. Fermentation of soybean meal with Aspergillus usamii reduces phosphorus excretion in chicks. Poult. Sci. 77:552-556.

Hong, K. J., C. H. Lee, and S. W. Kim. 2004. Aspergillus oryzae 3.042GB-107 fermentation improves nutritional quality of food soybeans and feed soybean meals. J. Med. Food 7:430434.

Hotz, C. and R. S. Gibson. 2007. Traditional food-processing and preparation practices to enhancing the bioavailability of micronutrients in plant-based diets. J. Nutr. 137:1097-1100.

Ilyas, A., M. Hirabayashi, T. Matsui, H. Yano, F. Yano, T. Kikushima, M. Takebe, and K. Hayakawa. 1995. A note on the removal of phytate in soybean meal using Aspergillus usami. Asian Australas. J. Anim. Sci. 8:135-138.

Jones, C. K., J. M. DeRouchey, J. L. Nelssen, M. D. Tokach, S. S. Dritz, and R. D. Goodband. 2010. Effects of fermented soybean meal and specialty animal protein sources on nursery pig performance. J. Anim. Sci. 88:1725-1732.

Kader, M. A., S. Koshio, M. Ishikawa, S. Yokoyama, M. Bulbul, B. T. Nguyen, J. Gao, and A. Laining. 2012. Can fermented soybean meal and squid by-product blend be used as fishmeal replacements for Japanese flounder (Paralichthys olivaceus)? Aquac. Res. 43:1427-1438.

Kishida, T., H. Ataki, M. Takebe, and K. Ebihara. 2000. Soybean meal fermented by Aspergillus awamori increases the cytochrome p-450 content of the liver microsomes of mice. J. Agric. Food Chem. 48:1367-1372.

Kwon, I. H., M. H. Kim, C. H. Yun, J. Y. Go, C. H. Lee, H. J. Lee, W. Phipek, and J. K. Ha. 2011. Effects of fermented soybean meal on immune response of weaned calves with experimentally induced lipopolysaccharide challenge. Asian Australas. J. Anim. Sci. 24:957-964.

Lena, D. G., E. Patroni, and G. B. Quaglia. 1997. Improving the nutritional value of wheat bran by a white rot fungus. Int. J. Food Sci. Technol. 32:513-519.

Li, D. F., J. L. Nelssen, P. G. Reddy, F. Blecha, J. D. Hancock, G. Allee, R. D. Goodband, and R. D. Klemm. 1990. Transient hypersensitivity to soybean meal in the early-weaned pig. J. Anim. Sci. 68:1790-1799.

Liener, I. E. 1994. Implications of antinutritional components in soybean foods. Crit. Rev. Food Sci. Nutr. 34:31-67.

Liu, X., J. Feng, Z. Xu, Y. Lu, and Y. Liu. 2007. The effects of fermented soybean meal on growth performance and immune characteristics in weaned piglets. Turk. J. Vet. Anim. Sci. 31:341-345.

Mathivanan, R., P. Selvaraj, and K. Nanjappan. 2006. Feeding of fermented soybean meal on broiler performance. Int. J. Poult. Sci. 5:868-872.
Moktan, B., J. Saha, and P. K. Sarkar. 2008. Antioxidant activities of soybean as affected by Bacillus-fermentation to kinema. Food Res. Int. 41:586-593.

Mukherjee, R., A. Dutta, and R. Chakraborty. 2015. Fermented soy products gaining popularity in poultry diets. All About Feed. 23:22-23.

Pinto, G. A. S., S. G. F. Leite, S. C. Terzi, and C. Couri. 2001. Selection of tannase-producing Aspergillus niger strains. Braz. J. Microbiol. 32:24-26.

Qin, G., E. R. ter Elst, M. W. Bosch, and A. F. B. van der Poel. 1996. Thermal processing of whole soya beans: Studies on the inactivation of antinutritional factors and effects on ileal digestibility in piglets. Anim. Feed Sci. Technol. 57:313-324.

Rigo, E., J. L. Ninow, M. Di Luccio, J. V. Oliveira, A. E. Polloni, D. Remonatto, F. Arbter, R. Vardanega, D. de Oliveira, and H. Treichel. 2010. Lipase production by solid fermentation of soybean meal with different supplements. LWT-Food Sci. Technol. 43:1132-1137.

Ross, P. R., S. Morgan, and C. Hill. 2002. Preservation and fermentation: past, present and future. Int. J. Food Microbiol. 79:3-16.

Singh, K., C. J. Linden, E. J. Johnson, and P. R. Tengerdy. 1990. Bioconversion of wheat straw to animal feed by solid substrate fermentation or ensiling. Indian J. Microbiol. 30:201-208.

Song, Y. S., J. Frias, C. Martinez-Villaluenga, C. Vidal-Valdeverde, and E. G. de Mejia. 2008. Immunoreactivity reduction of soybean meal by fermentation, effect on amino acid composition and antigenicity of commercial soy products. Food Chem. 108:571-581.

Song, Y. S., V. G. Pérez, J. E. Pettigrew, C. Martinez-Villaluenga, and E. G. de Mejia. 2010. Fermentation of soybean meal and its inclusion in diets for newly weaned pigs reduced diarrhea and measures of immunoreactivity in the plasma. Anim. Feed Sci. Technol. 159:41-49.

Teng, D., M. Gao, Y. Yang, B. Liu, Z. Tian, and J. Wang. 2012. Bio-modification of soybean meal with Bacillus subtilis or Aspergillus oryzae. Biocatal. Agric. Biotechnol. 1:32-38.

Yamamoto, T., Y. Iwashita, H. Matsunari, T. Sugita, H. Furuita, A. Akimoto,K. Okamatsu, and N. Suzuki. 2010. Influence of fermentation conditions for soybean meal in a non-fish meal diet on the growth performance and physiological condition of Rainbow trout Oncorhynchus mykiss. Aquaculture 309:173180

Yang, Y. X., Y. G. Kim, J. D. Lohakare, J. H. Yun, J. K. Lee, M. S. Kwon, J. K. Park, J. Y. Choi, and B. J. Chae. 2007. Comparative efficacy of different soy protein sources on growth performance, nutrient digestibility, and intestinal morphology in weaned pigs. Asian Australas. J. Anim. Sci. 20:775-783.

Yuan, Y. C., Y. C. Lin, H. J. Yang, Y. Gong, S. Y. Gong, and D. H. Yu. 2013. Evaluation of fermented soybean meal in the practical diets for juvenile Chinese sucker, Myxocyprinus asiaticus. Aquac. Nutr. 19:74-83.

Zamora, R. G. and T. L. Veum. 1979. Whole soybeans fermented with Aspergillus oryzae and Rhizopus oligosporus for growing pigs. J. Anim. Sci. 48:63-68. 